\title{
Analysing and Comparing Strategies of Public and Academic Libraries regarding their Period, their Vision and Mission as well as Values and Strategic programs
}

\author{
Petra Düren \\ Professor, PhD \\ Faculty of Design, Media and Information, \\ Hamburg University of Applied Sciences \\ E-mail petra.dueren@haw-hamburg.de \\ Ane Landøy \\ Academic librarian \\ University of Bergen Library \\ E-mail ane.landoy40@gmail.com
}

Strategic planning in academic and public libraries is vital and gaining importance in libraries all over the world. In this research project - using the qualitative method of documentary research based on "convenience sampling" - 33 strategies from libraries from eleven countries are analysed regarding their time period, vision and mission, as well as values of the libraries, and their strategic programs. This research analyses only 33 libraries from eleven different countries, as not every library has published its strategy and a lot of libraries do not have a strategy at all. As such the results of this research are limited and cannot be transferred to all libraries, however interesting results could still be found. Of the analysed libraries one-third have not formulated a vision, about two-thirds did not write down their mission and more than half of them did not express their values. All libraries have developed strategic ideas and programs to develop their library, their staff as well as their services. Another interesting aspect is that not all aspects of the libraries' values have been considered and are included in the libraries'strategic programs.

There are good and complete library strategies published, but more can be done in developing and implementing strategies in libraries - probably worldwide. This documentary research is helpful, as not only can be seen where libraries are heading in the future, but it can also help library leaders of libraries without a current strategy to gain ideas and transfer those to their own libraries .

Keywords: academic library, documentary research, mission, public library, strategy, strategic planning, values, vision 


\section{Introduction}

Strategic planning in academic as well as public libraries is vital and gaining importance in libraries all over the world.

"Strategies are as follows:

- forward looking;

- long term;

- include plans and actions;

- aim to ensure success; and

- act at different levels.

To put it in a nutshell, strategy closes the gap between the current state of an organization and the state that the organization wants to reach in the future; it is the planned path to future success" (Fuehles-Ubach 2018 p. 147). "But what is success in a public organization? Unlike in corporations, it is not sales and revenue generation that is of most interest in the public sector but the stakeholder value, and this means meeting the expectations of the stakeholders, i.e. both funders and users" (Fuehles-Ubach 2018 p. 147).

A research study on strategies of European libraries and their connection to the sponsoring organization concluded (Fühles-Ubach 2018 pp. 403-410) that a library strategy - as a visible and detectable contribution of the library - can affect the perception of the management of the library's sponsoring organization (Fühles-Ubach 2018 p. 403).

"... there is no such thing as a perfect strategy and all strategies, by virtue of the dynamic environment in which they exist, have to be dynamic" (Kearns 2010 p. 4).

But even knowing this, huge differences in the completeness as well as the quality of the libraries' strategies have been found. This research will highlight some of the differences between the analysed strategies, but also shows what they have in common, and what they consider the most important topics for the future.

\section{Research Method}

To find out more about strategies of academic as well as public libraries, the qualitative method of documentary research based on "convenience sampling" has been used. Convenience sampling means that cases have been selected and used, where easy access to the library's strategy was possible (Flick 2014 p. 166). With this kind of method it is not possible to generalize the results to all libraries with strategic plans (Schnell et al. 2013 p. 370), but it is impossible to gain access to all strategies of all libraries worldwide; especially as not all of them are published at all or published in English or one of the langeuages the authors of this paper can read. If documents are used they should be subject of the conducted research, e. g. their characteristics (Flick $2014 \mathrm{p}$. 324-325). For this to find strategies a GOOGLE-search was conducted in July 2020 (using the search terms "Library Strategy" and "Strategie Bibliothek") as well as libraries that were known for having a strategy published have been searched directly. Only libraries with its own strategies (published as pdf-documents) which are not included in e. g. the University's or the community's strategy have been chosen. Also internal strategy documents have been used. Especially the search for German libraries with strategies was a challenge. As Fühles-Ubach already found out during her research, German-language libraries are still in their infancy compared to Anglo-American libraries in this field which also affects their willingness to publicly publish their strategies, even if they have one (Fühles-Ubach 2018 p. 405). With this obviously far fewer strategies from German-language libraries have been published than from libraries in other countries (Fühles-Ubach 2018 p. 148). 
Even in the USA e. g. one cannot find at the "Professional Resources" of the ALA American Library Association something regarding academic libraries strategies (ALA American Library Association 2021 n. p.) which can be interpreted as a lead that library strategies are not a wellresearched and actual topic.

In total this research uses a sample of 33 strategies libraries from 11 different countries who published their strategy in English, German, Norwegian or Swedish.

To be able to compare the different library strategies the following characteristic factors and content have been analysed in detail:

- $\quad$ Period of the strategic plan because "Strategic Management is medium- and long-term, i. e. conceptually it tries to bridge periods of 3 to 10 years from the present to the target point." (Baldegger 2012 p. 108),

- $\quad$ Vision and mission as the strategic framework (Baldegger 2012 p. 112),

- $\quad$ Values of the library because values with behavioural principles can be important guidelines for day-to-day decisions for all members of the library, and help executing the strategy (Wunder 2016 p. 155), and

- $\quad$ Strategic programs / spheres of activity with their goals because "Strategic thinking is goal oriented, i. .e. it is geared in primarily towards future desired states and not so much towards current opinions" (Baldegger 2012 p. 108).

The first step was to find out if each strategic plan includes all these factors and content. The second step was to analyse these in detail to find out which are the key aspects mentioned in the strategy.

\section{Research Results}

33 strategies of academic as well as public libraries and school libraries from 11 different countries have been analysed for this research project. Details can be seen in the following table.

The first table shows which library strategies have been used in this research and how many academic libraries' and how many public libraries' strategies have been analysed. It also shows in which countries these libraries are originated.

\begin{tabular}{|l|l|l|l|}
\hline $\begin{array}{l}\text { Academic Libraries } \\
\text { (incl. University Libraries, } \\
\text { Research Libraries, and } \\
\text { National Libraries) }\end{array}$ & Public Libraries & School Libraries & Country \\
\hline 0 & 5 & 0 & \\
\hline 1 & 0 & 0 & Australia \\
\hline 1 & 0 & 0 & Austria \\
\hline 4 & 1 & 0 & Denmark \\
\hline 2 & 1 & 0 & Germany \\
\hline 0 & 1 & 0 & Ireland \\
\hline 4 & 0 & 0 & New Zealand \\
\hline 2 & 1 & 0 & Norway \\
\hline 0 & 1 & 0 & Sweden \\
\hline 5 & 2 & 1 & Switzerland \\
\hline 1 & 0 & 0 & United Kingdom \\
\hline $\mathbf{2 0}$ & $\mathbf{1 2}$ & $\mathbf{1}$ & USA \\
\hline
\end{tabular}

Table 1 Studied library strategies from different countries 
An interesting finding is that 22 of the 33 libraries have formulated a vision (67\%), but only eight libraries $(24 \%$, see figure 1) have written a mission for their library. Values can be found in $42 \%$ of the strategies (14 libraries in total). "Together with the company's mission and values the vision represents a normative strategic guidepost that is supposed to frame strategy formulation. Whereas the vision states what the company ultimately wants to accomplish in the long run, the mission articulates why the company exists (purpose) and what it actually does, and the values represent ethical norms and standards that govern behaviour of individuals" (Wunder 2016 p. 20). This shows how these three elements of a strategy complement each other and only together complete a strategy. Wunder goes even further: "It seems almost impossible to formulate a strategy if the organization's mission and vision as well as the behavioural principles and rules [the organization's or library’s values] remain unclear" (Wunder 2016 p. 146).

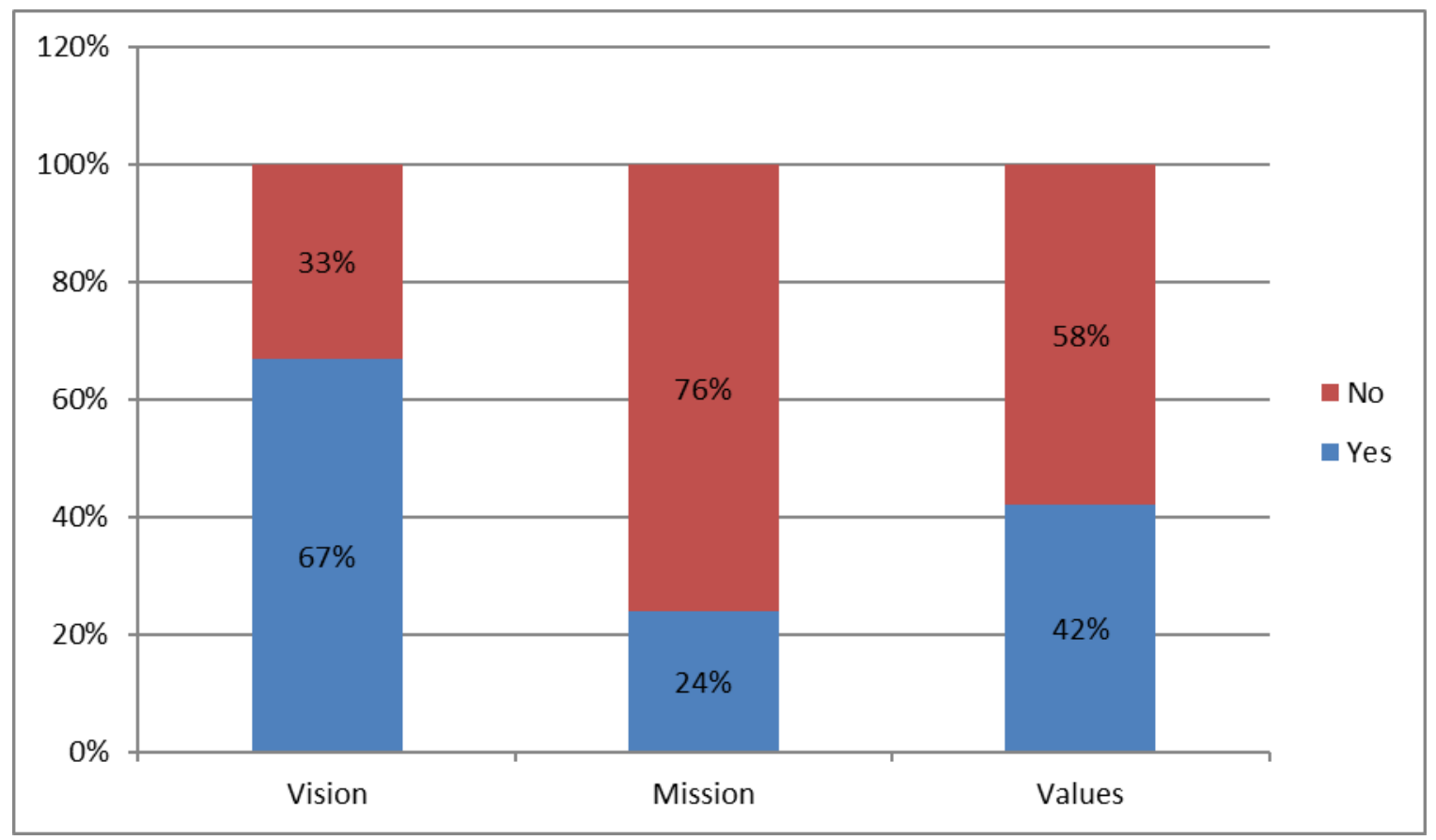

Figure 1 Vision, mission, and values found in the analysed library strategies

It is remarkable that none of the German libraries have published a vision, a mission, or values. This conforms to the results of the research of Fühles-Ubach that German-language libraries are still in their infancy in the field of developing a strategy (Fühles-Ubach 2018 p. 405; Fuehles-Ubach 2018 p. 148).

Also the duration of the libraries' strategies differ, as can be seen in chapter 3.1.

\subsection{Period of the strategic plan}

"The strategic planning system deals with defining long-range plans for where the company strives to be in three, five, ten or even more years..." (Wunder 2016 p. 318).

The strategies analysed in this research project range from three years to eleven years, as can be seen in table 2. Most libraries did their strategic planning for four, five or six years $(77.5 \%)$ and only two libraries planned for more than ten years. In two of the analysed strategies no period has been specified. 


\begin{tabular}{|l|l|l|}
\hline Years & Number of libraries & Percentage of libraries \\
\hline 3 & 3 & $9.7 \%$ \\
\hline 4 & 7 & $22.6 \%$ \\
\hline 5 & 7 & $22.6 \%$ \\
\hline 6 & 10 & $32.3 \%$ \\
\hline 7 & 1 & $3.2 \%$ \\
\hline 8 & 1 & $3.2 \%$ \\
\hline 11 & 2 & $6.5 \%$ \\
\hline
\end{tabular}

Table 2 Periods of the strategies analysed

To develop and implement a strategy is quite a long process, as it includes these five steps, which often are characterized by running through multiple cycles (forwards and backwards):

1. Goal formation (vision and mission),

2. Environmental analysis (external analysis),

3. Company analysis (internal analysis),

4. Choice of strategy, and

5. Strategy implementation (Bea \& Haas 2019 p. 59-60).

Therefore, strategies should not be developed for too short a period, and the task of the strategic planning process lies in securing the long-term success of a company or a public institution, such as academic and public libraries (Bea \& Haas 2019 p. 56). As several projects need years until they are finished - which also counts for a longer strategy period - "[s]trategic management is medium- and long-term, i.e. conceptually it tries to bridge periods of 3 to 10 years from the present to the target point" (Baldegger 2012 p. 108). This can also be seen in this research, as $77.5 \%$ of the libraries planned for four, five or six years.

Because of "today's dynamic and volatile environment" for all companies as well as libraries "strategy execution as well as strategic agility and adaptability are considered as particular important elements" (Wunder 2016 p. 49). This especially counts for those libraries that have a strategic plan for four, five or six years and even more for those that planned for up to eleven years.

\subsection{Vision and mission}

"The desired picture of the company's future is often articulated in terms of a vision" (Wunder 2016 p. 18). "It [...] sets the initial direction for strategic development" (Baldegger 2012 p. 142). This also counts for the libraries whose strategies have been analysed. As can be seen in figure 1, for more than half of the libraries' strategies (67\%) a vision has been formulated.

"A vision is an imaginative future picture of what the company wants to accomplish in the long run. It is the description of a desired future state of the organization" (Wunder $2016 \mathrm{p}$. 147). „Before strategies are formulated and a vision is stated, it makes sense for a company to stand back and consider or even refine why it actually exists" (Wunder 2016 p. 152).

A "vision only sets a general course and does not attempt to delve into specifics" (Kearns $2010 \mathrm{p}$. 24). It formulates a basic position, which marks the future directed orientation, giving the library a direction (Bea \& Haas 2017 p. 74). A vision formulates a standard at which members of the library's staff can and should orientate oneself (Hungenberg 2014 p. 418). Therefore, a vision should visualize an idea, which can be understood and shared by all members of staff (Hungenberg 2014 p. 419). 
In the following some visions will be analysed as examples.

\section{UiT The Arctic University of Norway Library:}

First and foremost, digital! ("Først og fremst digitalt!”) (UiT The Arctic University of Norway Library 2015 p. 1)

\section{Newcastle Libraries:}

"Our City, Our Stories, The Library.

A world class library for a smart, liveable and sustainable city.” (City of Newcastle n.d. p. 7)

\section{Library of Congress:}

"All Americans are connected to the Library of Congress." (Library of Congress n.d. p. 7, 9)

\section{School Libraries in Scotland (national strategy):}

"Scotland will have vibrant school library services that play a central role in helping children and young people gain the knowledge, skills and attributes needed for learning, life and work. They will provide a nurturing space to foster wellbeing and creativity across the school community." (SLiC Scottish Library \& Information Council n.d. p. 10)

\section{UCD Library:}

"A world class research library with a global reach, providing a welcoming and inclusive environment for learning, collaboration, knowledge creation and community. As partners in education and research and leaders in developing, managing and preserving library collections and providing information services, we will leverage technology and staff expertise to ensure the University's success in achievement of its mission and objectives." (The Library University College Dublin n.d. p. 4)

\section{Doncaster Council Public Libraries:}

"Our vision is for a library service which up to and by 2021;

1. Contributes to the fulfilment of a range of the local strategic partnership's objectives, with every library venue an asset to the community, which can be commissioned as a resource to support residents' economic, learning, and wellbeing needs;

2. Can work as an alternative service model which increases inward investment into the service and enables it to work more commercially (the right model for the service will be the one which enables the most investment to come in);

3. Provides excellent service delivery, demonstrated through a range of performance indicators." (Doncaster Council n.d. p. 3)

\section{The Library of Trinity College Dublin:}

"The overall vision is for the Library to be truly at the core of the Trinity College Dublin community, providing increasingly diverse services, facilities and partnerships to ever-widening, interdisciplinary academic fields; building on historic strengths and increasingly developing new areas; balancing Trinity College Dublin's international profile and its national responsibilities for the benefit of the entire community. The uniquely strong, public-facing aspect of the Library of Trinity College Dublin is a key area for development. Resourcing is increasingly challenging. Entrepreneurial partnerships with technology and business, with the city, promotion, marketing and significant philanthropy will be critical to success." (Trinity College Dublin, The University of Dublin n. d. p. 5)

"The vision is for the Library to be the physical and virtual "go-to" place to learn and to research" (Trinity College Dublin, The University of Dublin n.d. p. 6) 
As can be seen, visions range from very short versions (just one sentence / statement) to long explanations of what the library will be in the future. Two of these seven example libraries are going to be a "world class library" whereas only one has its focus on the digital aspect. One library is going to play a central role, one expects every of its library venues to be an asset to the community, one is going to be the "go-to" place physically as well as virtually to learn and to do research, and one library even expects all members of the whole country to be connected to it.

The main topics of the 22 visions that have been analysed are the following.

- Library is a world-class trademark:

world-class library

outstanding library

quality services and with this library as a trademark

- The library's role in development:

e. g. though helping children and young people to gain knowledge, skills and attributes needed for learning, life and work

e. g. through the development of the learning-environment at the university

enriching the community

- The library's support of learning, e. g. through:

connecting the community to learn, engage and inspire

providing a welcoming and inclusive environment for learning

support the residents' economic, learning, and wellbeing needs

open, safe and stimulating work environment

- The library becoming digital, e. g. through:

provision of innovative digital support for information literacy

selecting, collecting, arranging, making available and presenting relevant and quality assured sources of knowledge for researchers and students in both printed and electronic form

A "clear vision is the cornerstone of a win-win strategy but it also marks the first step towards your mission." (Kearns 2010 p. 25)

"A mission articulates the purpose or reason of the company's existence [...]. Whereas a vision is the aspired picture of the future, a mission is more immediate, relates to the firm's present purpose and typically has no due date" (Wunder 2016 p. 152). "The company's general objectives and behaviours are recorded in succinct form, but from a holistic point of view, in the mission statement" (Baldegger 2012 p. 146).

Some of the example libraries have not only formulated a vision, but also a mission (eight libraries in total). As "there are no binding rules for the detailed structuring of a mission statement" (Baldegger 2012 p. 146) these range from a very short version to a very detailed and long mission as can be seen in the following examples.

\section{Newcastle Libraries:}

"As a service to our community: We Enrich We Inspire We Strengthen" (City of Newcastle n.d. p. 7)

\section{Library of Congress:}

"Engage, inspire, and inform Congress and the American people with a universal and enduring source of knowledge and creativity. 
Service to Congress has been and remains at the core of our mission. We will continue to engage, inspire, and inform Congress through our collections and our diverse service and experience offerings, including policy consultations, on-demand analysis, briefings, events, programs, and constituent engagement.

As the steward of a unique, universal, and ever-growing collection that belongs to the American people, the Library of Congress also has a mandate to inspire, inform, and serve all Americans by engaging their cultural and intellectual curiosity and creativity.

Our mission in action takes many forms:

Engage

Researchers and authors turn to the Library for source material not available anywhere else. With access to original manuscripts, ancient maps, rare books, photographs, films, and sound recordings, these authors create new works that help interpret history for future generations. The process of copyright registration and deposit completes a virtuous cycle that may result in the addition of these new works to the Library's collections.

The Library helps ensure that millions of Americans with blindness and other disabilities continue to experience the joy of reading through a national network of libraries that distribute the latest contemporary literature in a variety of accessible formats.

Inspire

With 1.6 million annual visitors, the Library's Thomas Jefferson Building has become a landmark destination, renowned for its architectural beauty and celebration of knowledge and creativity.

Programs, exhibitions, centers, and marquee events such as the Veterans History Project, National Book Festival, and Digital Learning Labs expand the Library's reach and inspire learners of all ages.

Inform

Congress, the judiciary, and other federal agencies have reliable, round-the-clock access to reliable knowledge in print, online, and via consultation with scholars and experts from the Congressional Research Service, the U.S. Copyright Office, the Law Library, and the Kluge Center.

Families seeking to research their heritage can rely on subject experts in our reading rooms, tap into the StoryCorps Archive, or take advantage of the vast digital collections of early American newspapers, manuscripts, maps, photographs, and prints." (Library of Congress n.d. p. 7-8)

\section{UCD Library:}

"To organise and support the University's information to inspire engagement and learning, to enable its use in promoting research and innovation, and to contribute to the preservation of Irish cultural heritage resources." (The Library University College Dublin n.d. p. 4)

Only three of the seven deeper analysed example libraries with a vision (see above) have formulated a mission. It is interesting that all three of these libraries see it as their duty and mission to inspire others.

Even though library leaders have to consider that "if you do not include a mention of your employees needs in your mission statement you have already sent a very negative signal that they are not part of the big picture; their interests are not as important as stakeholders" (Kearns 2010 p. 28), none of the three example libraries have the members of staff included in their missions.

Library leaders also have to be aware of the challenge, that "formulating the mission statement concisely is often a problem. A balancing act between empty phrases and detailed instructions has to be successfully managed" (Baldegger 2012 p. 147). Nevertheless "many companies articulate their purpose in a brief, easy to understand and convincing mission statement..." (Wunder $2016 \mathrm{p}$. 153). "Easy to understand" holds true for all three examples, as all these missions are so formulated that all members of staff as well as its different groups of stakeholders can get the idea of the mission. But the mission of the Library of Congress is quite long and with this far from brief and concisely formulated. 
All three libraries make it clear and emphasize, that their mission is to be of service (to their respective communities, and for the Library of Congress to the Congress) as well as to organize and support.

\subsection{Values of the library}

The mission and values of a library frames their vision and therefore helps it come true (Wunder 2016 p. 145). "Organizational values are essential and enduring standards and norms of social behavior that are collectively held by members inside the company" (Wunder 2016 p. 155) respectively the library.

Values with up to five or six behavioural principles can be important guidelines for day-to-day decisions for all members of the library, and help executing the strategy (Wunder 2016 p. 155156).

Even if values are essential and important guidelines, only in 14 of the 33 analysed library strategies values were they found, which is in less than half of them (approximately $42 \%$ ).

In the following, main and important topics of the values of these 14 libraries are analysed further. Topics mentioned include

a. Employees / Staff

b. Community

c. Individual Development / Empowerment of users

d. Inclusion / Diversity / Integration / Equity / Equality / Respect / Tolerance

\section{a. Employees / Staff:}

In (only) five of the 14 analysed libraries' values were something written about the library's employees and staff. It is mainly about the expertise, knowledge and competence of the staff, as well as their development, as can be seen in the following.

\section{UCL (University College London) Library Services:}

"UCL Library Services is empowering our staff and our users.

Our staff are skilled and knowledgeable experts." (UCL Library Services n.d. p. 9)

\section{The Library University College Dublin:}

"We value Library staff by

- recognising that staff expertise, skills and personal commitment underpin the continuing success of the Library and the accomplishment of Library and University strategic objectives

- supporting the requirement for continuous professional development

- providing an inclusive working environment and treating all staff with dignity and respect" (The Library University College Dublin n.d. p. 4)

\section{University of Bergen:}

"UB emphasizes a high level of expertise in library employees." ("UB vektlegger høy kompetanse hos bibliotekets ansatte") (UIB University of Bergen Library n.d. p. 9)

\section{Arctic University Library:}

"Professionalism, development, cooperation and trust" ("Profesjonalitet, utvikling, samarbeid og tillit") (UiT The Arctic University of Norway Library 2015 p. 1)

\section{Österreichische Nationalbibliothek:}

We support education and training of our users and the increase in our staff's competences. ("Wir unterstützen die Aus- und Weiterbildung unserer BenutzerInnen und den Kompetenzzuwachs unserer MitarbeiterInnen.") (Österreichische Nationalbibliothek n.d. p. 5) 


\section{b. Community:}

Only four libraries emphasize their tasks and the importance of their services for their community.

\section{Public Libraries Ireland:}

"The public library service is a civic resource rooted in our communities. The library supports community life and individual self-development." (Department of Rural and Community Development 2018 p. 15)

\section{UCL (University College London) Library Services:}

"We are community-minded, inclusive and innovative." (UCL Library Services n.d. p. 9)

\section{The Library University College Dublin:}

"working smarter together across administrative boundaries to actively build partnerships at local, regional, national and international level to achieve service levels and access to resources for our community that may otherwise be unobtainable" (The Library University College Dublin n.d. p. 4)

Bayside Library Services:

"Public Value

As a part of the strategic service review process it was considered that the Bayside Library Service can deliver public value by:

- $\quad$ Enriching the lives of individuals within the Bayside Community by presenting an equal opportunity for social inclusion and engagement, and by developing and fostering reading and literacy skills for people of all ages.

- Delivering access to, and leadership in, information provision and technological advancements whilst adapting to changing societal demands.

- $\quad$ Nurturing community identity by preserving local history and offering a centrepiece at the heart of the community that shapes our public realm and maximises our shared value whilst simultaneously connecting individuals to the wider world." (Bayside City Council n. d. p. 17)

\section{c. Individual development / Empowerment of users:}

\section{Public Libraries in Ireland:}

"The public library service is a civic resource rooted in our communities. The library supports community life and individual self-development." (Department of Rural and Community Development 2018 p. 15)

\section{Österreichische Nationalbibliothek:}

"We stand for free access to knowledge. If people be able to freely access our holdings around the world, we enable creativity and inspiration. With this we contribute to more social development and progress." ("Wir stehen für einen freien Zugang zum Wissen. Wenn Menschen auf der ganzen Welt an unseren Beständen ungehindert teilhaben können, ermöglichen wir Kreativität und Inspiration. Damit tragen wir zu gesellschaftlicher Entwicklung und Fortschritt bei.") (Österreichische Nationalbibliothek n.d. p. 5)

UCL Library Services:

"UCL Library Services is empowering our staff and our users." (UCL Library Services n.d. p. 9) (Universitetsbiblioteket i Oslo 2010 p. 3) 
Oslo University Library:

"Availability

The University Library shall work to ensure that all libraries at UiO are universally organized so that everyone has access to and can easily find what they need in our services and premises."

("Tilgjengelighet - Universitetsiblioteket skal arbeide for at alle bibliotek ved UiO er universelt tilrettelagt slik at alle har adgang til og lett kan finne fram i våre tjenester og lokaler.") (Universitetsbiblioteket i Oslo 2010 p. 3)

\section{Yarra Libraries:}

"Our libraries provide a place for all people to connect with others, discover new things and find inspiration, both within the library walls and beyond." (Yarra Libraries / Yarra City Council n.d. p. 6)

Bayside Library Services:

"The library service provides access to information, resources, programs and spaces for all ages to learn, imagine, create and connect ..." (Bayside City Council n.d. p. 5)

\section{d. Inclusion / Diversity / Integration / Equity / Equality / Respect / Tolerance:}

\section{UCD Library:}

"UCD Library embraces the University's values of excellence, integrity, collegiality, engagement, and diversity. We value our students, faculty, staff and visitors by

- providing a welcoming physical and online environment

- responding flexibly and empathetically to changing circumstances and emerging needs

- treating all with dignity and respect and with consistency and impartiality, assuring equity of access to services and facilities

- being open and accountable in all that we do

- working smarter together across administrative boundaries to actively build partnerships at local, regional, national and international level to achieve service levels and access to resources for our community that may otherwise be unobtainable" (The Library University College Dublin n.d. p. 4)

"We value Library staff by

- [...] providing an inclusive working environment and treating all staff with dignity and respect" (The Library University College Dublin n.d. p. 4)

\section{University of Bergen Library:}

Respect

-UB's services and organization must emphasize inclusion, equality and diversity. ("UBs tjenester og organisasjon skal vektlegge inkludering, likestilling og mangfold“")

- Library users shall be met with tolerance and generosity. ("Bibliotekbrukere skal møtes med toleranse og raushet") (UIB University of Bergen Library n.d. p. 11)

UCL Library Services:

"We are community-minded, inclusive and innovative." (UCL Library Services n.d. p. 9) 
University of West London Library:

"Inclusive and open" (University of West London Library 2018 p. 2)

Gothenburg University Library:

"The library should pay special attention to users with special needs." ("Fortsätta att utveckla vår lässervice för studenter och personal med särskilda behov.") (Gothenburg University Library 2017).

\section{Bayside Library Services:}

"The library service provides access to information, resources, programs and spaces for all ages to learn, imagine, create and connect; contributing to a sense of belonging, enriched social life, wellbeing and liveability in Bayside." (Bayside City Council n.d. p. 5)

These main topics of the analysed libraries' values refer to users as well as staff and can help reaching the strategic goals, because "vision, mission, values and strategy are essential complements that need to be aligned with each other" (Wunder 2016 p. 146). The following analysis regard the strategic programs/spheres of activity.

\subsection{Strategic programs/Spheres of activity}

All the 33 libraries examined have written down strategic programs / spheres of activity. However, it was not always easy to recognize them as strategic programs and to distinguish them from strategic goals, as different terms have been used.

"Strategic thinking is goal oriented, i.e. it is geared primarily towards future desired states and not so much towards current options" (Baldegger 2012 p. 108). Also "strategic thinking is anticipatory, i.e. it tries to identify future developments and orient itself towards these in its shaping activities" (Baldegger 2012 p. 109). This can be seen in all analysed libraries' strategic programs.

The most often mentioned topics of the strategic programs are

- (Lifelong) Learning (17 libraries),

- Research (15 libraries),

- Digitisation Digitalization/Digital/Digitized (14 libraries),

- Space/Place (14 libraries), and

- Staff/Workforce / Employees / Personnel Development (11 libraries).

Also often mentioned are

- Community (8 libraries)

- Excellence / Excellent (5 libraries),

- Quality (5 libraries), and

- Networking/Network (4 libraries)

The most mentioned topics in the libraries' visions, "becoming world-class" (mentioned in one of the strategic programs) "with high quality", "offering a good learning-environment and support of learning" as well as "becoming digital", are included in up to 17 libraries.

Another comparison of the strategic programs with the libraries' values shows that not all topics of the values have found their way into the strategic programs. Especially individual development (of users, not of members of staff) and the empowerment of users are not mentioned in any of the libraries' strategic programs. Also, only three of the analysed library strategic programs say something about inclusion, diversity, integration, and equality. Respect and tolerance are not mentioned at all. 


\section{Conclusions}

Even if "it seems almost impossible to formulate a strategy if the organization's mission and vision as well as the behavioural principles and rules [the organization's or library's values] remain unclear" (Wunder 2016 p. 146), of the 33 analysed libraries 33\% have not formulated a vision, $76 \%$ did not write down their mission and 58\% did not express their values. One reason might be that there are not enough library management specialists working in libraries who have a deeper knowledge in developing a strategy. E. g. Koizumi and Widdersheim did not found any business management library specialist in their research using a sample of 60 US research libraries to investigate current specialties in academic librarianship (Koizumi \& Widdersheim 2019, p. 1, 47).

But all libraries have developed strategic ideas and programs to develop their library, their staff as well as their services, because "... a strategic document [...] is supposed to provide strategic guidance for the company [here the library] and direct behavior as well as resources toward strategic priorities" (Wunder 2016 p. 318). The most often mentioned topics for the future development of libraries are (Lifelong) Learning, Research, Digitalization, Space, and Staff / Personnel Development. All of these topics have been discussed and developed throughout the last years, but there still seems to be a lot do in libraries.

Some of the most often mentioned topics of the libraries' values are inclusion and diversity. Actual topics which will be interesting to see how they develop during the next years, especially as they are published by IFLA (The International Federation of Library Associations and Institutions) as one of the sustainability goals relevant for libraries: "In the UN 2030 Agenda, access to information has been recognised as a target under Sustainable Development Goal 16: Promote peaceful and inclusive societies for sustainable development, provide access to justice for all and build effective, accountable and inclusive institutions at all levels: 'Target 16.10: Ensure public access to information and protect fundamental freedoms, in accordance with national legislation and international agreements.' (Transforming our world: the 2030 Agenda for Sustainable Development)“"(IFLA 2020 n.p.).

This research analysed only 33 libraries from 11 different countries, as not every library have published its strategy, a lot of libraries do not have a strategy at all and there have been languagelimitations. With this the results of this research are limited and cannot be transferred to all libraries. But there have been some interesting results which may be of help for other libraries to develop their own strategy, such as

- Vision, mission and values are not included in every strategy and are not the starting point for developing a strategy, even if vision and mission function as the strategic framework (Baldegger 2012 p. 112) and values with their behavioural principles can be important guidelines for day-to-day decisions for all members of the library, and help executing the strategy (Wunder 2016 p. 155); here future research is needed if these strategies could be successfully reached even if vision, mission or values are missing.

- Not all aspects of the libraries' values have been considered and are included in the libraries' strategic programs; also there could be found strategic goals with no relation to the vision. As the "... vision is an imaginative future picture of what the company wants to accomplish in the long run" (Wunder 2016 p. 147) this might be adequate, but as this is noticeable there should be another research, why vision and strategic programs are not related closer or if the strategic programs are usually developed independent of the vision in libraries.

All in all the first point shows that it is possible to develop a strategy without a vision, mission or values, even if Wunder says that "vision, mission, values and strategy are essential complements that need to be aligned with each other" (Wunder 2016 p. 146), but if these strategies are successful is unclear. 
The second point shows the importance of using the library's values - if existent - as a basis for formulating a strategic program, so that nothing important is missing in the strategic program or that the strategic program is heading in the wrong direction.

All in all it can be said that good libraries' strategies may be found. Still, more can be done in developing and implementing strategies in academic and public libraries probably worldwide. 


\section{References}

American Library Association (ALA) ed. (2009) Professional Resources: A to Z Index of Topics [online], April 6, available: https://www.ala.org/tools/topics/atoz [accessed 4 August 2021].

Baldegger, R. (2012) Management in a Dynamic Environment: Concepts, Methods and Tools, Springer: Gabler Verlag Wiesbaden, available: DOI 10.1007/978-3-8349-3748-3.

Bayside City Council ed. (n. d.) Future Stories: Strategic Plan 2018-2022: Modern Library Services for the Bayside municipality [online], available: https://www.bayside.vic.gov.au/sites/default/ files/library/library_services_strategic_plan_2018-2022.pdf [accessed 14 July 2020].

Bea, F. X. and Haas, J. (2019) Strategisches Management [Strategic Management], 10th ed., München: UVK Verlag.

City of Newcastle ed. (n. d.) The Library Strategy 2019-2023 [online], available: http:// www.newcastle.nsw.gov.au/Newcastle/media/DocumentsHYS/Engagement\%20Projects/

Library\%20Strategy/The-Library-Strategy_March-2019.pdf [accessed 7 July 2020].

Department of Rural and Community Development ed. (2018) Our Public Libraries 2022: Inspiring, Connecting and Empowering Communities [online], available: https://www.gov.ie/en/ publication/56d1d4-our-public-libraries-2022-inspiring-connecting-and-empowering-commun/ [accessed 14 July 2020].

Doncaster Council ed. (n. d.) Doncaster Council Public Libraries Strategy 2018-2021 [online], available: $\quad$ https://ibrary.doncaster.gov.uk/documents/10158/18024/ Public+Libraries+Strategy+2018-21a.pdf/c71abc70-f9dc-4799-a9ec-1c0fd2b2e493 [accessed: 8 July 2020].

Flick, U. (2014) Qualitative Sozialforschung: Eine Einführung [Qualitative Social Research: An Introduction], 6th ed., Hamburg: Rowohlt Verlag.

Fuehles-Ubach, S. (2018) What is your contribution to the funder's strategy?, Library Management, 39 (3/4) pp. 146-153, available: DOI 10.1108/LM-10-2017-0112

Fühles-Ubach, S. (2018) Mittendrin oder nur dabei? Welche Rolle spielen Bibliotheken und ihre Strategien im Gesamtkontext ihrer Träger? [Right in the middle or just there? What role do libraries and their strategies play in the overall context of their providers?], BIBLIOTHEK - Forschung und Praxis, 42 (3) pp. 403-410, available: doi.org/10.1515/bfp-2018-0050

Gothenburg University Library ed. (2017) Strategisk plan 2017-2020 [Strategic plan 2017-2020] [online], unpublished, available: https://medarbetarportalen.gu.se/ digitalAssets/1665/1665143_strategisk-plan-2017-2020.pdf [accessed 15 July 2020]

Hungenberg, H. (2014) Strategisches Management in Unternehmen: Ziele - Prozesse - Verfahren [Strategic management in companies: goals - processes - procedures], 8th ed., Springer: Gabler Verlag Wiesbaden, available: DOI 10.1007/978-3-658-06681-9

IFLA ed. (2020) Libraries, Development and the United Nations 2030 Agenda [online], available: https://www.ifla.org/libraries-development [accessed 4 August 2021]

Kearns, P. (2010) HR Strategy: Creating Business Strategy with Human Capital, 2nd ed., Oxford: Elsevier.

Koizumi, M. and Widdersheim, M. M. (2019) Specialties and strategies in academic libraries: a cluster analysis approach, Library Management, 40 (1/2) pp. 45-58, available: DOI 10.1108/LM10-2017-0114

Library of Congress ed. (n. d.) Enriching the Library Experience: The FY2019-2023 Strategic Plan of the Library of Congress [online], available: https://www.loc.gov/strategic-plan/ [accessed 8 July 2020] 
SLiC Scottish Library \& Information Council ed. (n. d.) Vibrant Libraries, Thriving Schools: A National Strategy for School Libraries in Scotland 2018-2023 [online], available: https:// scottishlibraries.org/advice-guidance/national-strategies/the-national-strategy-for-school-libraries/ [accessed 8 July 2020]

The Library University College Dublin ed. (n. d.) UCD Library Strategy 2016- 2020: Embracing information opportunities to deliver the library of tomorrow [online], available: https://

www.ucd.ie/library/contact/strategy/ [accessed 8 July 2020]

Trinity College Dublin, The University of Dublin ed. (n. d.) The Library of Trinity College Dublin - Strategy 2015 - 2020 [online], available: https:/www.tcd.ie/library/about/strategy.php [accessed 8 July 2020]

UCL Library Services ed. (n. d.) UCL Library Services Strategy 2019-22 [online], available: https://www.ucl.ac.uk/library/about-us/ucl-library-services-strategy-2019-22 [accessed 14 July 2020]

UIB University of Bergen Library ed. (n. d.) Strategisk plan 2016-2022 [Strategic plan 20162022] [online], unpublished, available: https:/www.uib.no/sites/w3.uib.no/files/attachments/ ub_strategiplan_endelig_versjon_2016-2022_v4_web.pdf [accessed 30 March 2021]

UiT The Arctic University of Norway Library ed. (2015) Strategisk plan for Universitetsbiblioteket 2015-2020 [Strategic plan for the University Library 2015-2020] [online], available: https://uit.no/Content/424232/Strategi_2015-2020.pdf [accessed 7 July 2020]

Universitetsbiblioteket i Oslo ed. (2010) Strategi 2020 [Strategy 2020] [online], available: https:// www.ub.uio.no/om/strategi-plan-rapport/strategi-2020.pdf [accessed 15 January 2021]

University of West London Library ed. (2018) Library Services Strategy 2018-23 [online], available: https://www.uwl.ac.uk/current-students/library/library-policies-and-regulations/libraryservices-strategy-2018-2023 [accessed 15 January 2021]

Wunder, T. (2016) Essentials of Strategic Management: Effective Formulation and Execution of Strategy [online], Stuttgart: Schäffer-Poeschel Verlag.

Yarra Libraries and Yarra City Council ed. (n. d.) Library Strategic Plan 2017-2020 [online], available: https://library.yarracity.vic.gov.au/about-us/library-policies [accessed 15 January 2021] 